\title{
European species of the subgenus Brachylimnophila (Diptera: Limoniidae)
}

\author{
Jaroslav Starý \& Herbert Reusch
}

Starý, J. \& Reusch, H. 2008: European species of the subgenus Brachylimnophila (Diptera: Limoniidae). - Entomol. Fennica 19: 207-217.

The subgenus Brachylimnophila Alexander, 1966 is transferred from Neolimnomyia Séguy, 1937 in Dicranophragma Osten Sacken, 1860. The latter is elevated to genus rank. Three European species are redescribed, viz. Dicranophragma (Brachylimnophila) nemorale (Meigen, 1818), comb. n., D. (B.) separatum (Walker, 1848), comb. n. and $D$. (B.) adjunctum (Walker, 1848), comb. n. Lectotypes of $D$. (B.) separatum and $D$. (B.) adjunctum are designated. Male and female terminalia of the three species are illustrated, and their distributions are outlined.

J. Stary, Department of Zoology and Laboratory of Ornithology, Faculty of Science, Palacký University, tr. Svobody 26, CZ-771 46 Olomouc, Czech Republic; E-mail: stary@prfnw.upol.cz

H. Reusch, BAL - Bureau for Applied Limnology and Landscape Ecology, Wellendorf 30,D-29562 Suhlendorf, Germany; E-mail: herbert.reusch@t-online.de

Received 28 June 2007, accepted 1 November 2007

\section{Introduction}

Brachylimnophila was erected by Alexander (1966a) as a subgenus of Limnophila Macquart, 1834 for L. brevifurca Osten Sacken, 1860 (type species of Brachylimnophila), from Canada and USA, and some other species, including two occurring in Europe, Limnophila nemoralis (Meigen, 1818) and L. adjuncta (Walker, 1848). Later, Savchenko (e.g. 1979, 1983, 1986) transferred the subgenus Brachylimnophila in Neolimnomyia Séguy, 1937, which he restored as a valid genus. This shift in classification was based on some characters present in both Neolimnomyia and Brachylimnophila and absent in most other genera of the subfamily Limnophilinae. In particular, the terminal section of $R_{1}$ is longer than $R_{2}$ in the two taxa and in alignment with the rest of $R_{1}$, there is a tendency to re- duction of the cell $\mathrm{M}_{1}$, and the interbases of the male terminalia are present (cf. Savchenko 1986). Brachylimnophila comprises currently 11 species from the Nearctic, Palaearctic and Oriental regions (Oosterbroek 2007). The monotypic Mixolimnomyia Savchenko, 1979, with N. (M.) rufula Savchenko, 1979, from the Caucasus, has been considered another subgenus of Neolimnomyia.

In addition to the two European species, Neolimnomyia (Brachylimnophila) nemoralis and $N$. (B.) adjuncta, both commonly reported in the literature, Edwards $(1921,1938)$ commented on additional forms of uncertain status. Of these, $N$. (B.) separata (Walker, 1848) and $N$. (B.) minuscula (Edwards, 1921) were recently accepted as separate species, based on external characters (Stubbs 1997). However, these two names did not appear as valid species in the Brit- 
ish Checklist (Stubbs 1998). N. (B.) separata was newly recorded in Germany by Reusch \& Oosterbroek (2000) and Reusch et al. (2004). Previously, it was mentioned from Ukraine (Savchenko 1986: 325), with some doubts about its species status.

The aim of this paper was: (1) to check the status of the three forms, $N$. (B.) nemoralis, $N$. (B.) separata and $N$. (B.) adjuncta, and, if they are confirmed as valid species, to present their distinguishing characters, and (2) to examine the types of $N$. (B.) separata and $N$. (B.) adjuncta from the Natural History Museum, London, and to fix them accordingly to stabilise the current concept of the names.

The present examination has revealed that the three forms are specifically distinct, being distinguished by external characters, such as the body colouration, wing venation and wing pattern, and, as shown herewith, by both the male and female terminalia. The distinctions in the structure of the male terminalia are slight but constant, and are, surprisingly, supported by convincing female differences in the size of the spermathecae. The redescriptions are presented below. The lectotypes of $N$. (B.) separata and $N$. (B.) adjuncta are designated.

The type material of $N$. (B.) nemoralis was not studied, but the bicoloured appearance of the species, with a light grey thorax and pale brown abdomen, a character unique within European Limnophilinae, is clearly apparent from the original description (Meigen 1818). Other forms mentioned by Edwards (1938) and Stubbs (1997) were not revised, nor could they be recognised in the limited Scottish material available, and are here retained in the synonymy of $N$. (B.) nemoralis based on the current classification (Stubbs 1998, Oosterbroek 2007).

Acronyms of museums and collections used in the text are as follows: BMNH - The Natural History Museum [formerly British Museum (Natural History)], London, England, UK; HRS Collection of Herbert Reusch, Suhlendorf, Germany; JSO - Collection of J. Starý, Olomouc, Czech Republic.

Colour characters of species are described from dry-mounted specimens. Unless otherwise stated in the sections on Material examined, the material under study is dry-mounted.

\section{Systematic position of Brachylimnophila}

The male terminalia of various species more or less closely related to Brachylimnophila were examined. This examination included Limnophila (Dicranophragma) fuscovaria Osten Sacken, 1860 (type species of Dicranophragma Osten Sacken, 1860), from Canada and USA, and $L$. (D.) formosa Alexander, 1920, from the Russian Far East, Japan and Taiwan. Dicranophragma has currently 35 Nearctic, East Palaearctic, Oriental and Afrotropic species and subspecies, with a marked concentration of the species in the Oriental region (Oosterbroek 2007). The wing pattern of these species is conspicuous, consisting of several larger markings at the anterior margin and additional spots and dots, thus resembling the condition in the nominotypical subgenus of Limnophila Macquart, 1834 and the genus Eloeophila Rondani, 1856. They differ from them and other limnophilins by the presence of a supernumerary cross-vein in the cell $\mathrm{R}_{3}$. However, the male terminalia of Dicranophragma are similar to those of Brachylimnophila to an extent that leaves no doubt that the two are congeneric despite the very different general appearance [for formosa, see Savchenko \& Krivolutskaya 1976, Fig. 24a, b (male terminalia); other species e.g.: dorsolineata (Taiwan), see Alexander 1930, Fig. 26; laetithorax (China: Sichuan), see Alexander 1933, Fig. 32; microspila (Japan), see Alexander 1953, Fig. 19)].

The fact that Dicranophragma most closely resembled Brachylimnophila in the hypopygial structures was stressed by Alexander (1966a). At that time, both were considered subgenera of Limnophila. However, after Neolimnomyia was restored as a valid genus by Savchenko (1983), with Brachylimnophila included in it as a subgenus, Dicranophragma and Brachylimnophila were inappropriately separated. The male terminalia of both have the same general plan, with some parts surprisingly similar in structure: the outer gonostylus is slender, smooth, shortly bidentate at apex; the inner gonostylus is fleshy, more or less conical; the interbase is well-developed, generally spoon-like or paddle-like. The single male genital character distinguishing the two taxa seems to be the structure of the 
parameres; these are separate in Brachylimnophila, whereas, in Dicranophragma, they are fused to each other to form a shelf below the aedeagus.

Hence, practically as a by-product, the following change in classification is proposed: Dicranophragma, formerly a subgenus of Limnophila, is elevated to genus rank, with the subgenera Dicranophragma s. str. and Brachylimnophila (possibly also Mixolimnomyia). Neolimnomyia, apparently related to Dicranophragma, is retained as a separate genus, without subgeneric division.

\section{Redescriptions}

\subsection{Genus Dicranophragma Osten Sacken, 1860 , stat. nov.}

Dicranophragma Osten Sacken 1860: 240 (as subgenus of Limnophila; original description). Type species: Limnophila fuscovaria Osten Sacken, 1860 (Nearctic), by monotypy. - Alexander 1943: 378, 382 (reprinted 1966b) (as subgenus of Limnophila; key, diagnoses of North American species); Alexander 1965: 65 (as subgenus of Limnophila; Nearctic catalogue); Alexander \& Alexander 1973: 159 (as subgenus of Limnophila; Oriental catalogue); Hutson 1980: 74 (as subgenus of Limnophila; Afrotropical catalogue); Savchenko et al. 1992: 223 (as subgenus of Limnophila; Palaearctic catalogue); Oosterbroek 2007 (as subgenus of Limnophila; electronic World catalogue).

\subsection{Subgenus Brachylimnophila Alexander, 1966}

Brachylimnophila Alexander 1966a: 119 (as subgenus of Limnophila; original description). Type species: Limnophila brevifurca Osten Sacken, 1860 (Nearctic), by original designation. - Alexander \& Alexander 1973: 159 (as subgenus of Limnophila; Oriental catalogue); Savchenko 1986: 318, 323 (as subgenus of Neolimnomyia; key, diagnosis); Savchenko 1989: 94, 95 (as subgenus of Neolimnomyia; key, diagnosis); Savchenko et al. 1992: 224 (as subgenus of Neol- imnomyia; Palaearctic catalogue); Oosterbroek 2007 (as subgenus of Neolimnomyia; electronic World catalogue).

\subsection{Dicranophragma (Brachylimnophila) nemorale (Meigen, 1818), comb. $n$. (Figs 1a, d, g)}

Limnobia nemoralis Meigen 1818: 126 (original description).

Limnophila nemoralis: de Meijere 1921: 77 (redescription), Text-fig. 14 (wing), Pl. 7, Fig. 114 (male terminalia); Edwards 1921: 224 (diagnosis); Pierre 1924: 124, 127 (key, diagnosis), Figs 492 (wing), 499 (male terminalia); Nielsen 1925: 85 (diagnosis), Fig. 80 (wing); Czižek 1931: 135, 137 (key, diagnosis), Figs 78a-b (male terminalia, wing); Edwards 1938: 89 (as subgenus "Pilaria?"; diagnosis), Pl. 3, Fig. 17 (wing).

Neolimnomyia (Brachylimnophila) nemoralis: Savchenko 1978: 65 (note), Fig. 2 (male terminalia); Savchenko 1986: 324 (redescription), Figs 162/3 (wing), 166/3 (male terminalia); Savchenko et al. 1992: 225 (Palaearctic catalogue); Stubbs 1997: 8-9 (in error as Neolimnophila; key), Figs (wing); Podenas et al. 2006, Figs XVI.b (wing), 54.3 (wing), 54.4 (male terminalia); Oosterbroek 2007 (electronic World catalogue).

Limnobia leucophaea Meigen 1818: 127 (original description).

Limnobia plebeia Meigen 1818: 127 (original description).

Limnobia inclusa Walker 1848: 41 (original description).

Limnophila nemoralis var. collina Edwards 1921: 224 (original diagnosis).

Limnophila nemoralis var. minuscula Edwards 1921: 224 (original diagnosis).

Limnophila (Pilaria?) nemoralis var. minuscula: Edwards 1938: 90 (diagnosis).

Neolimnomyia (Brachylimnophila) minuscula: Stubbs 1997: 8-9 (in error as Neolimnophila; key), Fig. (wing).

Limnophila nemoralis var. quadrata Edwards 1921: 224 (original diagnosis).

Limnophila (Pilaria?) nemoralis var. quadrata: Edwards 1938: 90 (diagnosis). 


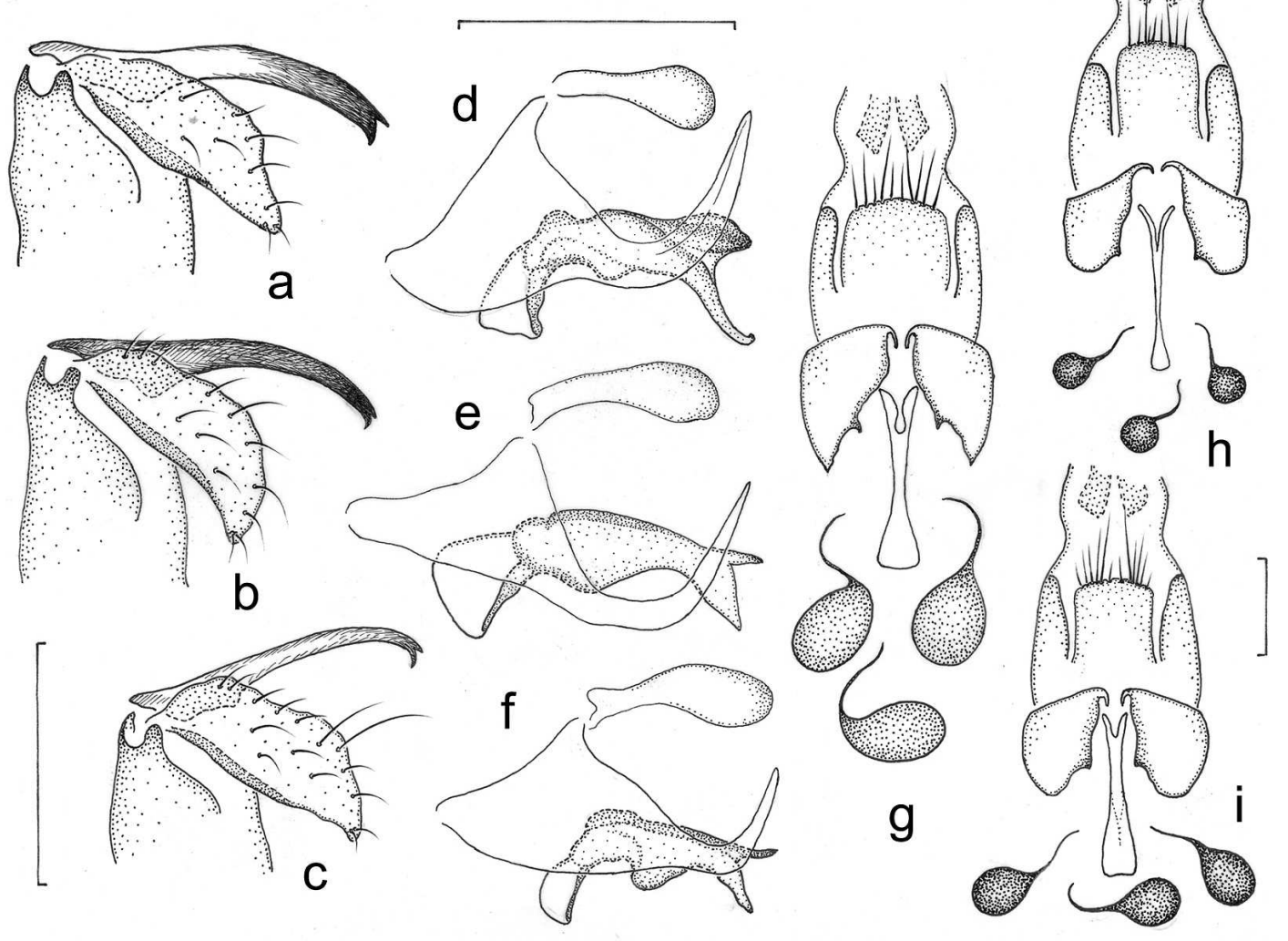

Fig 1. Male and female terminalia of Dicranophragma (Brachylimnophila) nemorale (Meigen, 1818), D. (B.) separatum (Walker, 1848) and $D$. (B.) adjunctum (Walker, 1848). - a-c. Male terminalia, gonostyli, dorsal: $D$. (B.) nemorale (a), D. (B.) separatum (b), D. (B.) adjunctum (c). - d-f. Male terminalia, aedeagal complex, lateral: $D$. (B.) nemorale (d), D. (B.) separatum (e), D. (B.) adjunctum (f). - g-i. Female terminalia, internal structures, ventral: $D$. (B.) nemorale (g), D. (B.) separatum (h), D. (B.) adjunctum (i). Scale bars $0.25 \mathrm{~mm}$. D. (B.) nemorale, Czech Republic; $D$. (B.) separatum, Czech Republic; $D$. (B.) adjunctum, Great Britain, England.

Diagnosis. General colouration light grey on thorax, pale brown on abdomen. Wing narrow, with poorly distinct stigma. $\mathrm{M}_{1}$ and $\mathrm{M}_{2}$ much shorter than their petiole. Male terminalia with distal lower part of aedeagus long and sinuous. Female terminalia with large spermethecae. Body length $6.0-8.5 \mathrm{~mm}$, wing length $6.0-9.5$ mm.

Redescription. Male. Head light grey. Antenna moderate in length, reaching to about mid coxa, yellow at base, from flagellomere 2 darkened towards tip. Flagellomeres generally ovoid, progressively narrower. Longest verticils about three times as long as their respective flagellomeres.

Thorax light grey with slight bluish tinge, sometimes with four poorly distinct longitudinal stripes on prescutum. Wing comparatively narrow, almost four times as long as broad, tinged yellowish, with poorly distinct stigma; other markings only indicated by somewhat darker veins. Venation: $R_{2}$ more than twice its length beyond origin of $\mathrm{R}_{2+3} ; \mathrm{M}_{1}$ and $\mathrm{M}_{2}$ much shorter than their petiole, half length of the latter or less (exceptionally cell $M_{1}$ lacking on one wing). Legs yellow.

Abdomen generally pale brown, with setosity moderate; segment 8 darkened. Male terminalia (Figs la, d): Gonocoxite comparatively long and slender, cylindrical. Outer gonostylus generally slender, yet stouter than in other two species, moderately and more or less evenly arched, pale 
proximally, darkly pigmented in distal half, apex shortly bidentate. Inner gonostylus fleshy, conical. Interbase generally spoon-like or paddle-like. Paramere moderately long, rather stout. Aedeagus bipartite distally in lateral view; upper part generally rounded, lower part much longer and more slender, slightly sinuous.

Female resembling male in general appearance. Verticils shorter, about twice as long as their respective flagellomeres. Abdominal segment 8 not darkened. Female terminalia with internal structures as in Fig. 1g. Vaginal apodeme (genital fork) moderately long and rather broad. Spermathecae large, pale, ovoid.

Material examined. Bulgaria: Sandanski env., 3.v.1989, 1 ふै, 5.V.1989, 1 ふै, 1 o; Pirin Mts, Banderica (1,200 m a.s.1.), 5.VI.1968, 2 §; Bansko env., 23.VII.1987, 1 §;; Michurin, 1.VI.1968, 1 of (all J. Starý leg.) (JSO). Czech Republic: Bohemia: Doksy env., Břehyňský brook, 25.IX.2003, 1 ‡̂ (J. Starý leg.) (JSO). Moravia: Jeseníky Mts, Branná, "Dembauda" (900 m a.s.1.), 21.VII.1999, 1 đ̊ (at light); Nový Dvirr nr. Opava, 12.VI.1967, 1 j; Rešov, waterfall, 17.VI.1969, 1 đ̊; Hrubá Voda nr. Olomouc, 8.VI.1971, 1 9; Daskabát nr. Olomouc, 11.VII. 1979, 1 đ, 1 우 Kletné nr. Suchdol nad Odrou, 11.VIII.1978, 1 §̊; Štramberk, Kotouč - quarry, "Mokřadlo", 28.VI.2004, 3 ô, 1 \&; Hrobice nr. Zlín (Gottwaldov), 3.VIII.1982, 1 đิ, 17.VII. 1984, 1 đิ, 23.VII.1985, 1 § (at light); Náměšt' nad Oslavou, Oslava valley, 26.V.1983, 1 q; Brno - Hády, 6.VIII.1967, 1 §̊; Bítov, Vranov reservoir, 16.VI.1971, 1 jे; Popice nr. Znojmo, 11.VI.1967, 2 ô; Nejdek nr. Lednice, 17.IX.1997, 1 $\delta$, 2.VI.2005, 1 ; Rohatec nr. Hodonín, "Pánov", 18.V.1977, 1 đ̃, 21.VI.2005, 1 o (at light), "Hrubý Závidov", 30.VIII.1977, 1 đ; Radějov, Radějovka valley, 13.VII.1982, 1 đે, 1 q, 16.VI.1984, 1 §; Radějov, Lučina, 25.VI.

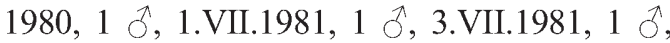
6.VII.1982, 2 đ̊; Bilé Karpaty Mts, Sůchovské Mlýny, Jamný, 7.VII.1994, 2 ô; Bílé Karpaty Mts, Javorník, "Machová", 20.VII.1993, 1 đ̊, 1 q (all J. Starý leg.) (JSO). Germany: BadenWürttemberg: Rot nr. Rot (590 m a.s.l.), 12.VI.1997, $2 \AA$ (R. Brinkmann leg.) (HRS, in ethanol); Greffern, Rheinaue, 23.VI.1995, 1 ơ (J. Starý leg.) (JSO). Bayern: Benninger Ried nr. Memmingen (600 m a.s.1.), 6.VIII.2003, 1 o, 6 q (light trap) (O. König et al. leg.) (HRS, in ethanol). Brandenburg: Geuenbach nr. Köpernitz (62 m a.s.1.), VIII.1992, 1 के (R. Brinkmann leg.); Siepgraben nr. Wulkow/Kyritz (42 m a.s.l.), 9.VI.2006, 1 (T. Berger leg.) (HRS, in ethanol). Mecklenburg-Vorpommern: Gingst/Rügen (10 m a.s.1.), 9.VI.1989, 1 ठै; Ralswick/Rügen (30 m.a.s.1.), 13.VI.1989, 2 ó (all R. Heiss leg.) (HRS, in ethanol). Niedersachsen: Ilmenau nr. Bad Bevensen (25 m a.s.1.), 5.VI.1993, 2 ô (R. Heiss leg.); Lutter nr. Bargfeld (62 m a.s.1.), 20.VII.-29.VIII.1990, 5 o (light trap) (T. Meineke leg.); Eisenbach nr. Wrestedt (40 m a.s.1.), 28.V.1999, $1 \delta$ (H. Reusch leg.) (HRS, in ethanol). Sachsen-Anhalt: Havelberg $(27 \mathrm{~m}$ a.s.1.), 9.VIII.99, 1 ô (light trap) (H. Reusch leg.) (HRS, in ethanol). Schleswig-Holstein: Unterer Schierenseebach nr. Hohenhude (7 m.a.s.1.), 10.VII.1987, 2 oे; 6.VI.-29.VII.1988, 12 $\hat{\sigma}, 7$ \%; Ratzeburg (10 m a.s.l.), 14.VI.1992, 1 के,

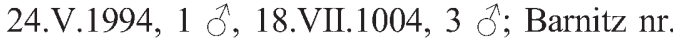
Kretholz(30 m a.s.l.), 4.VII.1994, 1 ơ; Lake-outlet nr. Groß Tremmerup (5 m a.s.l.), 13.VII.1994, 1 ; ; Friedeholz nr. Bockholm (10 m a.s.1.), 13.VII.1994, 1 ô, 1 o; Mühlenau nr. Altmühlendorf (20 m a.s.1.), 14.VII.1994, 1 §; Treene nr. Frörup (30 m a.s.1.), 21.VII.1998, $2 \hat{\jmath}, 2$ ( all R. Brinkmann leg.) (HRS, in ethanol). Thüringen: Vesserbach nr. Schmiedefeld (600 m a.s.l.), 18.VIII.1987, 2 § (emergence trap) (W. Joost \& W. Zimmermann leg.); Emse nr. Winterstein (390 m a.s.1.), 8.VIII.1997, 1 §ै; Hörsel nr. Hörselgau/Gotha (295 m a.s.l.), 14.VI.1998, 3 ठ (all R. Bellstedt leg.) (HRS, in ethanol). Luxembourg: Bech-Kleinmacher (200 m a.s.l.), 11.12.VIII.1998, 12 o (light trap) (M. Meyer leg.) (HRS, in ethanol). Slovakia: Šaštín (distr. Senica), 23.VI.1979, 1 ð̋; Závod nr. Malacky,

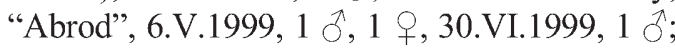
Nová Vieska nr. Štúrovo, 12.IX.1981, 1 ô, 26.IX.1983, 1 ô, 15.V.1984, 1 ô; Kamenný Most nr. Štúrovo, 19.VII.1983, 1 §, 24.IX.1983, $1 \delta$; Kamenica nad Hronom, Hron, 15.V.1984, 1 đ̊; Bajtava nr. Štúrovo, 1.VI.1982, 1 đ; Podhradie nr. Topol'čany, 21.VIII.1984, 1 đ̊; Stankovany, mineral spring, 16.VII.1985, $1 \hat{\delta}$, 12.VI.1987, 1 ठ̊; Zuberec, Pálenica Mt., 25.VI. 1998, 1 ; Kvetnica nr. Poprad, 1.VII.1979, 1 §; Belianske Tatry Mts, Tatranská Kotlina, Belá valley (750 m a.s.1.), 30.VI.1979, 2 ô (all J. Starý 
leg.); Giraltovce, 14.VII.1951, 1 † (J. Slípka leg.); Remetské Hámre, Okna valley, 13.VII. 1967, 1 đ̊; Ubl'a, Stežná shores, 23.VI.1983, 1 đ̊; Nová Sedlica, "Bahno", 7.VII.1993, 1 đ̊ (all J. Starý) (JSO).

Discussion. D. (B.) nemorale is distinctive by its bicoloured appearance, having a light grey thorax and a pale brown abdomen, and having narrow wings. In the structure of the male terminalia, it is characterised, above all, by the outer gonostylus (stouter than in separatum and adjunctum, moderately arched, pale proximally) and the aedeagus (lower distal part long and sinuous) (Figs 1a, d). The female terminalia have large, ovoid spermathecae (Fig. 1g). Although the external characters show closer affinities of $D$. (B.) nemorale to $D$. (B.) separatum, placing $D$. (B.) adjunctum somewhat apart based on the wing venation and wing pattern, genital features indicate a somewhat more isolated position of $D$. (B.) nemorale.

Distribution. D. (B.) nemorale appears to be widely distributed in the Palaearctic region, including Europe, North Africa, Middle Asia, West and East Siberia, Mongolia and the Russian Far East (for details, see Oosterbroek 2007). In contrast to $D$. (B.) separatum, it is mostly associated with lower altitudes, but the two species largely overlap in this respect (see also under separatum). Occurrance of $D$. (B.) nemorale at 1,200 $\mathrm{m}$ a.s.l. in the Bulagian Pirin Mts should be emphasised (see Material examined).

\subsection{Dicranophragma (Brachylimnophila) separatum (Walker, 1848), comb. n.} (Figs 1b, e, h)

Limnobia separata Walker 1848: 56 (original description).

Limnophila (Pilaria?) nemoralis var. separata: Edwards 1938: 90 (diagnosis).

Neolimnomyia (Brachylimnophila) separata: Stubbs 1997: 8-9 (in error as Neolimnophila; key), Fig. (wing); Oosterbroek 2007 (electronic World catalogue).

Diagnosis. General colouration dark greyish brown. Wing comparatively broad, with poorly distinct stigma. $M_{1}$ and $M_{2}$ much shorter than their petiole. Male terminalia with both distal parts of aedeagus short. Female terminalia with very small spermathecae. Body length 5.0-7.5 $\mathrm{mm}$, wing length $5.5-8.5 \mathrm{~mm}$.

Redescription. Male. Head dark grey. Antenna moderate in length, reaching to about mid coxa, mostly dark brown throughout. Flagellomeres generally ovoid, progressively narrower. Longest verticils about three times as long as their respective flagellomeres.

Thorax dark greyish brown, sometimes with four poorly distinct longitudinal stripes on prescutum. Wing rather broad, about three times as long as broad, tinged greyish, without any pattern except for poorly distinct stigma. Venation: $\mathrm{R}_{2}$ more than twice its length beyond origin of $\mathrm{R}_{2+3} ; \mathrm{M}_{1}$ and $\mathrm{M}_{2}$ much shorter than their petiole, half length of the latter or less (exceptionally cell $M_{1}$ lacking on one wing). Legs obscure yellow, with tips of femora infuscated.

Abdomen generally dark greyish brown, sometimes more brownish, with conspicuous setosity, long and suberect. Male terminalia (Figs $1 \mathrm{~b}, \mathrm{e})$ : Gonocoxite comparatively long and slender, cylindrical. Outer gonostylus more slender than that of $D$. (B.) nemorale, arched rather in distal half, darkly pigmented throughout, apex shortly bidentate. Inner gonostylus fleshy and conical. Interbase generally spoon-like or paddlelike. Paramere moderately long, more slender than that of $D$. (B.) nemorale. Aedeagus bipartite distally in lateral view, both parts short and subacute at tips, lower one broader than upper one.

Female resembling male in general appearance. Verticils shorter, about twice as long as their respective flagellomeres. Wing slightly narrower. Female terminalia with internal structures as in Fig. 1h. Vaginal apodeme (genital fork) longer and more slender than that of $D$. (B.) nemorale. Spermathecae very small, darkly pigmented, nearly spherical.

Type material examined. In describing Limnobia separata, Walker (1848: 56) only stated: "Hammerfest, Finmark. From Mr. Walker's collection." Lectotype $\delta$ (present designation): Norway (Province of Finnmark), Hammerfest (F. Walker leg.) (BMNH), labelled "Hammerf / Finmark", with reverse side "F. / Walker /... 37. / 11." (illegible where dotted) (circular label, handwritten), "Limnobia / separata / Walk." (handwritten), with printed inscription on reverse side 
"One of Walkers / series so named. / Edw", "Limnobia / separata, $\hat{\sigma} /$ Walker. / (Type)." (hand-written), "Holotype of / Limnobia separata / Walker 1848" (hand-written), "BMNH(E) \# / 247770" (printed), "Type" (green-margined circular label, printed), "HOLO- / TYPE." (redmargined circular label, printed). Labelled by the present authors as the lectotype ('LECTOTYPE/ Limnobia / separata Walker of / J. Starý \& H. Reusch 2006", printed red label) and identified as Dicranophragma (Brachylimnophila) separatum. The specimen is micro-pinned on a stage (white matter), with right antenna broken off (except for basal segments), only femur and tibia of mid right leg present, and with distal halves of both wings missing; apex of abdomen cut off. Terminalia dissected by the present authors and placed in a sealed plastic tube with glycerine, pinned with the specimen. According to N. Wyatt (e-mail comm.) this is the only type of Limnobia separata in BMNH, which seems to be confirmed by Edwards (1938: 90) who likewise commented on the single "Walker's type of separata..." (erroneously "from Finland"; Finnmark is a province of Norway). On the other hand, the note by Edwards on the reverse side of one label (see above) suggests that more specimens were available (or the printed note was intended for a different purpose, and only misused by Edwards). There is no statement about the number of specimens in the description by Walker (1848). Hence, the type specimen examined is designated here as the lectotype to maintain the concept of the name in case additional specimens may be found to exist (cf. Recommendation 73F of ICZN 1999).

Other material examined. Bulgaria: Pirin Mts, Banderica (over 2,000 m), 21.VII.1987, 4 đ, 1 f, 22.VII.1987, 2 đ, 3 \& (J. Starý leg.) (JSO). Czech Republic: Bohemia: Šumava Mts, Horská Kvilda, 5.VII.1992, 1 के, 10.VII.1992, 1 of (at light); Sumeva Mts, "Jezerní slat", 7.VII.1992, 2 ô; Sumava Mts, Borová Lada, 17.VIII.1968, 1 J̄; Šumava Mts, Pěkná, Vltava shores $(750 \mathrm{~m}$ a.s.l.), 4.VI.2004, 1 đ, 1 q; Radostín, Malé Dařko (620 m a.s.1.), 23.VIII.1981, 1 ठ̉ (all J. Starý leg.) (JSO). Moravia: Jeseníky Mts, Rejvíz (750 $\mathrm{m}$ a.s.l.), peat-bog, 5.VI.1967, 1 \&, 4.VIII.2004, 1 § (at light); Jeseníky Mts, Dětrrichov nr. Jeseník, 27.V.1969, 1 đ; Jeseníky Mts, Velký Kotel, 23.VI.1967, 1 đ̊; Jeseníky
Mts, Praděd, Bílá Opava valley (900-1,050 m a.s.1.), 14.VII.1994, 1 ઈ, 1 q, 26.VII.1994, 1 ‡; Jeseníky Mts, Kouty nad Desnou, Divoká Desná valley, "Zámčisko" (970 m a.s.1.), 14.VI.2004, 1 $\hat{\delta}$ (at light), 8.VII.2004, $2 \hat{\delta}$ (at light), 27.VII.2006, 4 ठ (at light); Dlouhá Loučka, "Valšovský žleb", 8 km N, 18.V.1989, 1 đే; Jívová nr. Olomouc, 14.VIII.1968, 1 đ̊; Krčmaň nr. Olomouc, 5.VII.1977, 1 ふ̊; Lazníky nr. Přerov, 17.V.1992, 1 đ̊, 9.VI.1992, 1 đ̊; Moravskoslezské Beskydy Mts, Prostřední Bečva (600 m a.s.1.), 30.VII.1992, 1 đ̊ (all J. Starý leg.) (JSO). Germany: Baden-Württemberg: Rohnbachtal nr. Enzklösterle/Schwarzwald (700 m a.s.1.), 24.VI.1992, $1 \precsim$ (R. Heiss leg.); Echaz nr. Honau (470 $\mathrm{m}$ a.s.1.), 12.VIII.1998, 1 ô (R. Brinkmann leg.) (HRS, in ethanol). Bayern: Röthenbach, Hoher Trauchberg nr. Halblech/ Ostallgäu (1,100 m a.s.1.), 30.VI.2000, 2 đ (A. Dorn \& A. Weinzierl leg.); Benninger Ried nr. Memmingen (600 m a.s.1.), 15.-20.VI.2003, 3 q (emergence trap) (S. Wiedenbrug leg.) (HRS, in ethanol). Mecklenburg-Vorpommern: Puttbus/ Rügen (20 m a.s.l.), 16.VI.1989, 3 o, 1 q; Lietzow/Rügen (30 m a.s.l.), 19.VI.1989, 1 ○ (all R. Heiss leg.) (HRS, in ethanol). Niedersachsen: Aschau nr. Beedenbostel (50 m a.s.l.), 31.VII.1991, 1 §; Örtze nr. Müden (55 m a.s.l.), 2.VI.1993, 1 đ; Steinkuhlenbergbach nr. Salzgitter-Osterlinde (130 m a.s.1.), 6.VII.1994, 1 ठ (all H. Reusch leg.); Örtze nr. Poitzen (58 m), 7.VI.1999, 3 đิ, 2 ㅇ (R. Brinkmann leg.) (HRS, in ethanol). Sachsen-Anhalt: Selke nr. Straßberg/Harz (450 m), 30.VII.2001, 2 今, 1 \& (R. Bellstedt leg.) (HRS, in ethanol). Schleswig-Holstein: Unterer Schierenseebach nr. Hohenhude (7 m a.s.1.), 1.VII-24.VIII.1987, 22 ö; 23.V.19.VIII.1988, 47 ð, 30 \&; 29.VI.-27.VII.1989, 6 $\hat{\jmath}, 1 \mathrm{q}$; Bille nr. Aumühle (11 m a.s.l.), 24.vi.1994, 1 đ̃; Bille nr. Sachsenwaldau (20 m a.s.1.), 24.VI.1994, 2 $\hat{\text {, }}$, Mühlenau nr. Altmühlendorf (20 m a.s.1.), 14.VII.1994, 1 §, 1 ; Ratzeburg (10 m a.s.l.), 18.VII.1994, 2 ; Vosskaten (50 m a.s.1.), 18.VII.1994, 1 స;; Barnitz nr. Kretholz (30 m), 28.VII.1994, 1 đ̊; Fuhlenau nr. Himmelreich (20 $\mathrm{m}$ a.s.l.), 14.VII.1999, 2 §, 2 ㅇ, 28.VI.2003, 1 (all R. Brinkmann leg.) (HRS, in ethanol). Thüringen: Friedrichsroda (425 m a.s.1.), 17.vii.1991, $1 \hat{\delta}$ (R. Heiss leg.); Schweina-Oberlauf nr. Schweina 
(480 m a.s.1.), 14.VII.2001, 1 (light trap) (R. Bellstedt leg.) (HRS, in ethanol). Great Britain: Scotland: Angus: nr. Kirriemuir, Glen Uig, 3.VII.1977, 2 §̧; nr. Kirriemuir, by Mile Hill, 5.VII.1977, 3 के nr. Kirriemuir, Glen Cally, 5.VII.1977, 5 oे; nr. Kirriemuir, Loch of Kinnordy, 6.VII.1977, 2 ö; nr. Dundee, Barry Links, 3.VII.1977, 1 \%; R. Isla, Den of Airlie, 4.VII.1977, 1 đ̊; nr. Newtyle, Pitnappie, 6.VII. 1977, 1 o; Perth: nr. Blairgowrie, Myreside, 4.VII.1977, 2 đ̊ (all A. M. Hutson leg.) (JSO). Slovakia: Suchá Hora, peat-bog, 9.VII.1988, 1 j; Západné Tatry Mts, Juráňova dolina [valley], "Tiesňavy" (880 m a.s.1.), 14.VI.2000, 1 ô; Západné Tatry Mts, Spálená dolina [valley] (1,300 m a.s.1.), 13.VI.2000, 1 đ̊; Západné Tatry Mts, Ráčková dolina [valley], 18.VII.1967, 1 q; Západné Tatry Mts, Jamnícka dolina [valley], 20.VII.1967, 1 ô, 1 \&; Vysoké Tatry Mts, Hrebienok, 19.VII.1969, 1 đ̊; Vysoké Tatry Mts, Vel'ká Studená dolina [valley], 23.VII.1969, 1 đ, 1 q; Vysoké Tatry Mts, Velické pleso [lake] (1,665 m a.s.1.), 18.VII.2001, 1 §, 24.VI.2002, 1 今ं; Belianské Tatry Mts, Dolina Sedmich pramen̆ov [valley], 30.VII.1974, 1 đ̊; Belianské Tatry Mts, Skalné Vratá, 24.VII.1969, 3 đ̊; Belianské Tatry Mts, Tatranská Kotlina, Šarpanec, 19.VI.1977, 1 đ̊; Belianské Tatry Mts, Tristárska dolina [valley] (1,100 m a.s.1.), 24.VII.1975, 1 ठै, 22.VI.1977, 2 3; Pol'ana Mts, Hronček valley (700-800 m a.s.1.), 26.V.2005, 1 đ̄; Sloveské Rudohorie Mts, Úhorná, 11.VII.1970, 1 đ; Nová Sedlica, "Stužica", 13.VI.1986, 1 ठ̊, 6.IX.1989, 1 ô, 1 q, 9.VII. 1993, 1 ô (all J. Starý leg.) (JSO). Switzerland: Canton Graubünden: Zernez (1,500 ma.s.1.), 4.VII.1979, 1 ô (C. Dufour leg.)(JSO).

Discussion. As compared to D. (B.) nemorale, $D$. (B.) separatum is generally darker, with the antennae dark throughout and the tips of femora infuscated, and it has broader wings. The redescription above is based on the specimens from the mountainous regions of the Czech Republic and Slovakia. Generally, D. (B.) separatum is somewhat variable in some external characters, such as the body colouration and the outline of the wings, most probably due to ecological conditions. In the series of the specimens from the Pirin Mts, Bulgaria (see Material examined), the body colouration is distinctly paler, rather pale greyish brown. The Scottish specimens (see Ma- terial examined) vary in both the body colouration and the outline of the wings. Some have the wings narrower (yet broader than those of nemorale), and the body shows a difference between the dark grey thorax and predominantly brown abdomen (the latter sometimes banded with dark brown), resembling thus somewhat darker specimens of $D$. (B.) nemorale. The antennae of all these specimens are more or less uniformly dark (occasionally, the first flagellomere is slightly paler than both the following flagellomeres and the basal segments), and the tips of the femora are infuscated. In the structure of the male terminalia, $D$. (B.) separatum is somewhat similar to $D$. (B.) adjunctum, but the outer gonostylus is darker and less curved before the apex, the parameres are longer and the two distal parts of the aedeagus unequal in shape (Figs 1b, e). The female terminalia have very small spermathecae, nearly spherical (Fig. 1h), thus clearly distinct from the other two species.

Distribution. So far the species was only recorded in Great Britain, Germany and, somewhat questionably, in the Ukraine (Oosterbroek 2007). The record from the Ukraine is most probably right, and the species is here newly recorded for Bulgaria, Czech Republic, Slovakia and Switzerland. D. (B.) separatum has been considered a mountainous form, but a number of lowland records are known from Germany, as well as the syntopic occurrance of $D$. (B.) nemorale and $D$. (B.) separatum (see Material examined).

\subsection{Dicranophragma (Brachylimnophila) adjunctum (Walker, 1848), comb. n. (Figs 1c, f, i)}

Limnobia adjuncta Walker 1848: 40 (original description).

Limnophila (Pilaria?) adjuncta: Edwards 1938: 90 (diagnosis), Pl. 3, Fig. 16 (wing).

Neolimnomyia (Brachylimnophila) adjuncta: Savchenko 1986: 326 (redescription), Figs 162/4 (wing), 166/4 (male terminalia); Savchenko et al. 1992: 225 (Palaearctic catalogue); Stubbs 1997: 8-9 (in error as Neolimnophila; key), Fig. (wing); Podenas et al. 2006, Figs XVI.f (male terminalia), 54.1 (wing), 54.2 (male terminalia); Oosterbroek 2007 (electronic World catalogue). 
Limnophila axillaris Strobl 1906: 413 (original description).

Limnophila axillaris var? brevifurcata Strobl 1906: 414 (original diagnosis).

Limnophila dimidiata de Meijere 1918: 132 (original description).

Limnophila dimidiata: de Meijere 1921: 72 (redescription), Text-fig. 8 (wing), Pl. 6, Figs 109a-b (male terminalia); Pierre 1924: 128 (diagnosis), Figs 506 (wing), 511 (male terminalia).

Limnophila nemoralis var. noscibilis Edwards 1921: 225 (original diagnosis).

Diagnosis. General colouration greyish brown. Wing narrow, with distinct stigma and other spots or seams. $M_{1}$ and $M_{2}$ subequal in length to their petiole. Male terminalia with both distal parts of aedeagus short. Female terminalia with spermathecae moderately large. Body length 5.0-9.0, wing length 5.5-9.5 $\mathrm{mm}$.

Redescription. Head grey. Antenna moderate in length, reaching to about mid coxa, brown at base, darkened distally. Flagellomeres generally ovoid, progressively narrower. Longest verticils about three times as long as their respective flagellomeres.

Thorax grey, sometimes with four poorly distinct longitudinal stripes on prescutum. Wing comparatively narrow, almost four times as long as broad, tinged greyish. Stigma distinct, even if not especially pronounced, with other spots or seams at origin of Rs and so-called cord, i.e. at basal section of $\mathrm{R}_{5}, \mathrm{r}-\mathrm{m}$, basal section of $\mathrm{M}_{1+2}$ and m-cu. Venation: $R_{2}$ less than twice its length beyond origin of $\mathrm{R}_{2+3} ; \mathrm{M}_{1}$ and $\mathrm{M}_{2}$ subequal in length to their petiole. Legs obscure yellow.

Abdomen brown to dark greyish brown, with setosity moderate. Male terminalia (Figs 1c, f): Gonocoxite comparatively long and slender, cylindrical. Outer gonostylus very slender, almost straight proximally, considerably curved before apex, slightly pigmented throughout, apex shortly bidentate. Inner gonostylus fleshy, conical. Interbase generally spoon-like or paddle-like. Paramere shorter and than that of $D$. (B.) separatum. Aedeagus bipartite distally in lateral view, both parts short, subacute at tips and subequal in shape.

Female resembling male in general appearance. Verticils shorter than in male, about twice as long as their respective flagellomeres. Female terminalia with internal structures as in Fig. 1i. Vaginal apodeme (genital fork) much as in $D$. (B.) nemorale. Spermathecae intermediate in size between those of $D$. (B.) nemorale and $D$. (B.) separatum, darkly pigmented, ovoid.

Type material examined. In describing Limnobia adjuncta, Walker (1848: 40) only stated: "England. From Mr. Walker's collection." Lectotype $\delta$ (present designation): England (F. Walker leg.) (BMNH), labelled "adjuncta" (hand-written), "Pres. by / F. Walker / 56. 50." (hand-written), "Holotype of / Limnobia adjuncta / Walker, 1848 / England" (hand-written), "BMNH(E) \# / 235032" (printed), "Type" (green-margined circular label, printed, with hand-written inscription "Limnobia adjuncta"), "HOLO- / TYPE" (red-margined circular label, printed). Labelled by the present authors as the lectotype ("LECTOTYPE / Limnobia / adjuncta Walker đ / J. Starý \& H. Reusch 2006", printed, red label) and identified as Dicranophragma (Brachylimnophila) adjunctum. The specimen is "micro-pinned" (with rather a tip of normal pin) on a triangular celluloid point, with apex of left antenna broken off, left mid leg and parts of right fore and hind legs present; apex of abdomen cut off. Terminalia dissected by the present authors and placed in a sealed plastic tube with glycerine, pinned with the specimen. According to N. Wyatt (e-mail comm.) this is the only type of Limnobia adjuncta in BMNH. Since, however, as usually, there is no statement about the number of specimens in the description by Walker (1848), the type specimen examined is designated here as the lectotype to maintain the concept of the name in case additional specimens may be found to exist (cf. Recommendation 73F of ICZN 1999).

Other material examined. Germany: BadenWürttemberg: Obere Argen nr. Harratried (595 m), 19.viii.1998, 1 \& (R. Brinkmann leg.) (HRS, in ethanol). Great Britain: Wales (North): Caernarvon, Aberdaron, "swarming", 16.IX. 1966, 3 ; Caernarvon, Llanbedrog, grassy cliff, 11.IX.1966, 3 \& (all R. I. Vane-Wright leg.) (JSO). Greece: Crete: Khania Region: Nea Roumata, brook, 21.V.2004, 1 ઈे (J. Starý leg.); Prases, 4 km SW, 17.V.2004, 1 q (M. Vála leg.), 18.V.2004, 1 đ, 21.V.2004, 1 ô, 1 ㅇ (J. Starý leg.); Kavros, 19.V.2004, 2 ơ (J. Roháček \& M. Vála leg.), 24.V.2004, $10 \AA \hat{\jmath}, 5$ q; Kavros, 
Delfinado brook, 11.V.2004, 2 ठै (all J. Starý leg.). Italy: Sicily: Fiume Eleutero, $6 \mathrm{~km} \mathrm{SW}$ Marineo, forest above riverbanks near lake Scanzano (600 m a.s.1.), 19.X.1993, $1 \hat{\sigma}$ (P. Oosterbroek \& C. Hartveld leg.) (JSO). Luxembourg: Bech-Kleinmacher (200 m a.s.l.), 24.VII. 1998, 1 ठै (light trap) (M. Meyer leg.) (HRS, in ethanol). Switzerland: Canton Neuchâtel: Chambrelien, 24.IX.1994, 2 o (J. Starý leg.) (JSO).

Discussion. This is a very distinctive species, which differs from both $D$. (B.) nemorale and $D$. (B.) separatum by a distinct wing pattern and some features in the wing venation $\left(R_{2}\right.$ less than twice its length beyond origin of $\mathrm{R}_{2+3}, \mathrm{M}_{1}$ and $\mathrm{M}_{2}$ subequal in length to their petiole). The male terminalia, generally similar to those of $D$. (B.) separatum, have a very slender outer gonostylus, considerably curved before the apex, the parameres shorter and the two distal parts of the aedeagus subequal in shape (Figs 1c, f). The spermathecae are intermediate in size between those of $D$. (B.) nemorale and $D$. (B.) separatum (Fig. 1i). The specimens from Greece (Crete) (see Material examined) have $M_{1}$ and $M_{2}$ somewhat shorter than their petiole, often half as long.

Distribution. D. (B.) adjunctum has atlanticmediterranean distribution, ranging to North Caucasus and Georgia (Transcaucasia) (for details, see Oosterbroek 2007). The westernmost record is from Ireland, the northernmost from Lithuania. The species is here newly recorded for Greece (Crete) and Luxembourg.

Acknowledgements. For the loan of the type specimens of Limnobia separata Walker and L. adjuncta Walker, we are much indebted to N. P. Wyatt (BMNH). For the gift of specimens, we thank the following: R. Bellstedt (Gotha, Germany), T. Berger (Potsdam, Germany), R. Brinkmann (Schlesen, Germany), Antonie Dorn (Landshut, Germany), C. Dufour (Muséum d'histoire naturelle, Neuchâtel, Switzerland), R. Heiss (Frankfurt/Oder, Germany), A. M. Hutson (then BMNH), O. König (Krumbach, Germany), T. Meineke (Ebergötzen, Germany), M. Meyer (Natural History Museum of Luxembourg), A. Weinzierl (Landshut, Germany), W. Zimmermann (Weimar, Germany). The English text was checked and improved by Beate and Stephen Loftus (Wyoming, New South Wales, Australia). The work was supported by grant MSM6198959212 for the senior author.

\section{References}

Alexander, C. P. 1930: New or little-known Tipulidae from eastern Asia (Diptera), VII. - Philipp. J. Sci. 42: 507-535.

Alexander, C. P. 1933: New or little-known Tipulidae from eastern Asia (Diptera), XV. — Philipp. J. Sci. 52: 131-166.

Alexander, C. P. 1943: Family Tipulidae. - In: Crampton, G. C., Curran, C. H. \& Alexander, C. P. (eds.), Guide to the Insects of Connecticut. Part VI. The Diptera or true flies of Connecticut. First Fascicle. - Bull. Conn. St. geol. nat. Hist. Survey 64: 196 486. [reprinted in 1966]

Alexander, C. P. 1953: Records and descriptions of Japanese Tipulidae (Diptera), Part II. The crane-flies of Shikoku, II. - Philipp. J. Sci. 82: 141-179.

Alexander, C. P. 1965: Family Tipulidae. - In: Stone, A., Sabrosky, C. W., Wirth, W. W., Foote, R. H. \& Coulson, J. R. (eds.), A Catalog of the Diptera of America North of Mexico: 16-90. U. S. Department of Agriculture, Washington D. C., Agricultural Handbook 276. iv +1696 pp.

Alexander, C. P. 1966a: New subgenera and species of crane-flies from California (Ptychopteridae and Tipulidae, Diptera). — Trans. Am. Entomol. Soc. 92: 103 132.

Alexander, C. P. 1966b: Family Tipulidae. - In: Crampton, G. C., Curran, C. H. \& Alexander, C. P. (eds.), Guide to the Insects of Connecticut. Part VI. The Diptera or true flies of Connecticut. First Fascicle. - Bull. Conn. St. geol. nat. Hist. Survey 64: 196 486. [reprinted]

Alexander, C. P. \& Alexander, M. M. 1973: Family Tipulidae. - In: Delfinado, M. D. \& Hardy, D. E. (eds.), A Catalog of the Diptera of the Oriental Region, 1: 10 224. The University Press of Hawaii, Honolulu. 618 pp.

Czižek, K. 1931: Die mährischen Arten der Dipterenfamilien Limoniidae und Cylindrotomidae. - Z. mähr. Landesmus. 28: 1-207.

Edwards, F. W. 1921: British Limnobiidae: Some records and corrections. - Trans. R. Ent. Soc. Lond. 1921: $196-230$.

Edwards, F. W. 1938: British short-palped craneflies. Taxonomy of adults. - Trans. Soc. Br. Ent. 5: 1-168.

Hutson, A. M. 1980: Family Tipulidae. - In: Crosskey, R. W. (ed.), Catalogue of the Diptera of the Afrotropical Region: 47-91. British Museum (Natural History), London. 1437 pp.

ICZN 1999: International Code of Zoological Nomenclature. Fourth Edition. - The International Trust for Zoological Nomenclature, c/o the Natural History Museum, London. xxix +306 pp.

Meigen, J. W. 1818: Systematische Beschreibung der bekannten Europäischen zweiflügeligen Insekten. Erster Theil mit elf Kupfertafeln. - Beaufort Sohn, Aachen. xxxvi+333 pp.

Meijere, J. C. H. de 1918: Neue holländische Dipteren. Tijdschr. Entomol. 61: 128-141. 
Meijere, J. C. H. de 1921: Studien über palaearktische, vorwiegend holländische Limnobiiden, insbesondere über ihre Kopulationsorgane (Schluss). — Tijdschr. Entomol. 64: 54-118.

Nielsen, P. 1925: Stankelben. (The craneflies) — In: Danmarks Fauna 28. G. E. C. Gads Forag, København. 165 pp. [In Danish]

Oosterbroek, P. 2007: Catalogue of the Craneflies of the World (Diptera, Tipuloidea: Pediciidae, Limoniidae, Cylindrotomidae, Tipulidae). [www document] URL http://ip30.eti.uva.nl/ccw/stats.php (Last update: 11 Apr 2007).

Osten Sacken, C. R. 1860: New genera and species of North American Tipulidae with short palpi, with an attempt at a new classification of the tribe. - Proc. Acad. Nat. Sci. Philad. 1859: 197-256.

Pierre, C. 1924: Diptères: Tipulidae. - In: Faune de France 8. Paul Lechevalier, Paris. 159 pp.

Podenas, S., Geiger, W., Haenni, J.-P. \& Gonseth, Y. 2006: Limoniidae \& Pediciidae de Suisse. - In: Fauna Helvetica 14. CSCF \& SEG, Neuchâtel. 375 pp.

Reusch, H. \& Oosterbroek, P. 2000: Übersicht der aus den einzelnen deutschen Bundesländern bekannten Stelzmücken (Diptera: Limoniidae et Pediciidae). Braunschw. Naturkundl. Schr, 6: 149-164.

Reusch, H., Bellstedt, R., Brinkmann, R. \& Heiss, R. 2004: Regionale Ergänzungen zur Stelzmücken-Fauna Deutschlands in verschiedenen Bundesländern. Braunschw. Naturkundl. Schr. 7: 109-121.

Savchenko, E. N. 1978: (The fauna of Limoniid-flies (Diptera, Limoniidae) of the North Kuriles.) - In: Systematics and biology of the freshwater-organisms of north-east Asia. Trudy biol.-pochv. Inst. DVNC AN SSSR, Vladivostok (N.S.) 49: 63-68. [In Russian]
Savchenko, E. N. 1979: A new subgenus and a new species of Limoniid-flies from the genus Neolimnomyia Séguy (Diptera, Limoniidae). — Dopov. Akad. Nauk Ukr. RSR (B) 1979: 482-485. [In Ukrainian]

Savchenko, E. N. 1983: (Limoniidae of South Primorye.) —Akad. Nauk Ukr. SSR, Kiev. 156 pp. [In Russian]

Savchenko, E. N. 1986: (Limoniid-flies: Introduction; subfamilies Pediciinae and Hexatominae). - Fauna Ukrainy 14 (2). Naukova Dumka, Kiev. 380 pp. [In Russian]

Savchenko, E. N. 1989: (Limoniid-flies of the fauna of the USSR). - Akad. Nauk Ukr. SSR, Kiev. 377 pp. [In Russian]

Savchenko, E. N. \& Krivolutskaya, G. O. 1976: (Limoniidae of the South Kuril Islands and South Sakhalin). Akad. Nauk Ukr. SSR, Kiev, 160 pp. [In Russian]

Savchenko, E. N., Oosterbroek, P. \& Starý, J. 1992: Family Limoniidae. - In: Soós, Á., Papp, L. \& Oosterbroek, P. (eds.), Catalogue of the Palaearctic Diptera 1: 183-369. Hungarian Natural History Museum, Budapest. $520 \mathrm{pp}$.

Strobl, P. G. 1906: Spanische Dipteren, II. Beitrag (1). Mems. R. Soc. Esp. Hist. Nat. 3(1905): 271- 422.

Stubbs, A. E. 1997: Cranefly Recording Scheme. Test Key to Subfamily Limnophilinae. - Peterborough. $17 \mathrm{pp}$.

Stubbs, A. E. 1998: Limoniidae. - In: Chandler, P. (ed.), Checklists of Insects of the British Isles (New Series) Part 1: Diptera. Handbooks for the Identification of British Insects Volume 12: 4-9. Royal Entomological Society, London. 234 pp.

Walker, F. 1848: List of the specimens of dipterous insects in the collection of the British Museum 1. London. $229 \mathrm{pp}$. 